University of Nebraska - Lincoln

DigitalCommons@University of Nebraska - Lincoln

2006

Ecology in a Cost-Benefit Society: The Issues

Valery E. Forbes

University of Nebraska-Lincoln, veforbes@umn.edu

Peter Calow

Roskilde University

Follow this and additional works at: https://digitalcommons.unl.edu/biosciforbes

Part of the Pharmacology, Toxicology and Environmental Health Commons

Forbes, Valery E. and Calow, Peter, "Ecology in a Cost-Benefit Society: The Issues" (2006). Valery Forbes Publications. 41.

https://digitalcommons.unl.edu/biosciforbes/41

This Article is brought to you for free and open access by the Papers in the Biological Sciences at DigitalCommons@University of Nebraska - Lincoln. It has been accepted for inclusion in Valery Forbes Publications by an authorized administrator of DigitalCommons@University of Nebraska - Lincoln. 
Special Section

\title{
Ecology in a Cost-Benefit Society: The Issues
}

\author{
Valery E. Forbes \\ Department of Life Sciences and Chemistry, Roskilde University, Roskilde, Denmark (vforbes3@unl.edu)
}

and

Peter Calow

Velux Guest Professor, Roskilde University, Roskilde, Denmark

\begin{abstract}
Is there a role for ecology in a cost-benefit society? As a prelude to a collection of papers arising from a conference on this theme held at Roskilde University in June 2004, this paper summarizes divergent approaches to public policy decision making. Whether based on strict cost-benefit analysis or wide-ranging discussion, we make the point that decisions need to be informed by an understanding of the causes behind environmental problems and their consequences, through impaired ecosystem services, on the economy. Taking this forward will require forums that bring ecologists, economists, and regulators into active and constructive dialogue.
\end{abstract}

Keywords: Environmental Management, Risk assessment, Welfare economics, Willingness to pay

Article history: Received August 8, 2005; accepted October 15, 2005.

The concept of a cost-benefit society goes to the heart of public policy decision making in a world where time, effort, and resources inevitably are limited. Some argue that the ultimate arbiter of policy options in a democratic society should be public preferences, as expressed in willingness to pay; that the only way to make decisions about the adoption of policies therefore is by weighing the benefits and costs that are associated with rival options; and that this applies no less to environmental issues than it does in other areas (e.g., Pearce 1998). The welfare of society as a whole can be deduced from the preferences of the individuals within it. This often is referred to as the neoclassical, welfare economics approach.

On the contrary, others argue that by emphasising the desires of the individual, this market-orientated, reductionist approach will necessarily overlook the public good (e.g., Söderbaum 2000). Political institutions, unlike markets, function as forums in which participants with differing views about what is good for society (e.g., in terms of protecting habitats, species, and landscapes against human activities and developments) seek solutions through dialogue.

Much has been written criticizing both views in the extreme, and it sometimes is claimed that a 3rd way exists, one in which both the economics and the political processes have roles to play. Farber (1999) refers to this as ecopragmatism. It might be argued, for example, that the cost-benefit approach is particularly appropriate in limited situations (e.g., decisions about where to build a motorway), in which the costs and benefits are apparently straightforward to define and quantify, but not in more broadly based policy areas (e.g., global issues such as climate change). Others still might argue against this 3rd way, however, in that it makes too sharp a distinction between the interests of people as private consumers and as citizens (Pearce 1998).

Clearly, science has a place in all approaches by connecting adverse effects with causes and adverse effects with their consequences in terms of ecosystem processes and services. The challenge is in considering how the scientific understanding can effectively inform the judgments that are made during prioritization and valuation.

This debate has particular importance when considering environmental policy, where the entities in question are public goods. Yet even here, as important as environmental values are, at some point it would become absurd to pursue them at all costs. We inevitably have to value ecological entities in some sense, then weigh their values against other demands. Doing this in a systematic and transparent way, and using this to inform policy and decision making, whether based on the attempted precision of the welfare economics 
models and/or political debate, in our view gets to the heart of the environmental policy debate - that is, balancing economics with environment and social issues in an optimal way through time.

The papers brought together in this collection arise from the Conference on Ecology in a Cost-benefit Society, held at Roskilde University, Denmark, on June 1718,2004 . They reflect the range of viewpoints referred to above, with, for example, Hanley and Black (2006) and Schou et al (2006) taking more of a strict neoclassical approach and Söderbaum (2006) promoting positional analysis rather than a cost-benefit approach. Costanza (2006) advocates a more broad-based approach to cost-benefit analysis that includes consideration of a wider range of valuation methods than normally employed, as well as consideration of distributional consequences. The part played by science in defining effects, their causes, and their consequences in decision making is addressed most explicitly by Hanley and Black (2006), Costanza (2006), and Gray (2006). An important challenge in ensuring that public preferences are informed by an understanding of the scientific evaluation of risks is developing appropriate tools for communicating complex concepts of risk to consumers. This is addressed by Saouter and Andreasen (2006).

Public preferences about environmental issues, whether expressed through willingness to pay and/or the democratic political process, need to be informed by scientific understanding. For example, if decisions are made to control the wrong cause of an environmental problem, the end result will be no environmental benefits but many economic costs. Also, if an understanding of all the consequences of environmental impacts on ecosystem services is lacking, it becomes impossible to give a full value to the economic benefits that might be lost as a result of human intervention.

The debate at the Roskilde Conference focused on the way that public preferences are expressed in the decision-making process. At the conference, we began to consider the challenge of integrating scientific understanding into the process. An important conclusion from the conference was the need for effective forums that bring ecologists, economists, and regulators into active and constructive discussion and debate.

\section{References}

Costanza, R. 2006. Thinking broadly about costs and benefits in ecological management. Integr Environ Assess Manag 2: 166-173.

Farber, D.A. 1999. Eco-Pragmatism. Chicago, Ill.: University of Chicago Press. $210 \mathrm{p}$.

Gray, J.S. 2006. Minimizing environmental impacts of a major construction: the Øresund Link. Integr Environ Assess Manag 2: 196-199.

Hanley N., A.R. Black. 2006. Cost-benefit analysis and the Water Framework Directive in Scotland. Integr Environ Assess Manag 2: 156-165.

Pearce, D. 1998. Valuing risks. In: P. Calow, editor. Handbook of Environmental Risk Assessment and Management. Oxford, U.K.: Blackwell Science. p. 345-375.

Saouter, E., I. Andreasen. 2006. www.scienceinthebox. com: Procter \& Gamble's experience of the costs and benefits of communicating product safety information to the public via the internet. Integr Environ Assess Manag 2: 191-195.

Schou, J., B. Hasler, B. Nahrstedt. 2006. Valuation of biodiversity effects from reduced pesticide use. Integr Environ Assess Manag 2: 174-181.

Söderbaum, P. 2000. Ecological Economics: Political Economics for Social and Environmental Development. London, U.K.: Earthscan. 224 p.

Söderbaum, P. 2006. Cost-benefit analysis, democracy, and sustainable development-What is the alternative to CBA? Integr Environ Assess Manag 2: 182-190. 